\title{
Perlindungan Hukum Keputusan Bisnis Direksi BUMN Melalui Business Judgement Rule Doctrine
}

\section{Mochammad Abizar Yusro}

Fakultas Hukum, Universitas Brawijaya, Malang

Email: abizar.yusro@gmail.com

\section{Ali Ismail Shaleh}

Fakultas Hukum, Universitas Diponegoro, Semarang

Email: aliismailshaleh@gmail.com

\section{Hari Sutra Disemadi}

Fakultas Hukum, Universitas Diponegoro, Semarang

Email: haridisemadi@gmail.com

DOI: 10.23917/jjr.v10i1.11006

\section{Submission \\ Track: \\ ABSTRAK \\ Received: \\ Tujuan: Penelitian ini bertujuan untuk mengkaji dan menganalisis \\ 31 Mei 2020 perlindungan hukum terhadap keputusan bisnis Direksi BUMN yang dikriminalisasi akibat keputusan bisnis tersebut merugikan keuangan negara.}

Final Revision:

Metodologi: Penelitian yang bersifat deskriptif ini menggunakan 26 Juli 2020 metode penelitian hukum normatif yang mengedepankan pada data sekunder. Pendekatan yang digunakan pada penelitian ini adalah pendekatan perundang-undangan dan pendekatan konseptual.

Temuan: Hasil penelitian ini menunjukkan perlindungan hukum yang Available online: diberikan kepada Direksi BUMN dalam mengambil keputusan bisnisnya dapat berupa hak imunitas, yang mana dengan hak ini

31 Juli 2020

Corresponding Author: seorang Direksi BUMN dapat terlepas dari pertanggungjawaban pidana apabila Direksi tersebut dapat membuktikan bahwa keputusan bisnis yang telah diambil dan dijalankan telah sesuai dengan prinsipprinsip bisnis yang layak (business judgement rule) sesuai ketentuan yang termuat dalam Undang-Undang Perseroan Terbatas.

Hari Sutra

Disemadi

Kegunaan: Hasil penelitian ini dimaksudkan agar dapat berkontribusi dalam literatur mengenai perlindungan hukum bagi keputusan bisnis 
Direksi BUMN yang telah dikriminalisasi.

Kebaruan/Orisinalitas: Berbeda dengan penelitian terdahulu, pada penelitian ini menunjukkan business judgment rule doctrine dapat dipergunakan untuk menlindungi keputusan bisnis Direksi BUMN yang merugikan negara dan penelitian ini berfokus pada perlindungan hukum keputusan bisnis Direksi BUMN setelah adanya Putusan Mahkamah Konstitusi Nomor No. 48/PUU-XI/2013 dan 62/PUUXI/2013.

Keywords: Perlindungan Hukum, Keputusan Bisnis, Direksi BUMN, Business Judgment Rule Doctrine.

\section{PENDAHULUAN}

Dewasa ini, perkembangan pembangunan perekonomian baik skala internasional maupun nasional menjadi fokus pelaksanaan maupun penyelenggaraan di suatu negara. Di Indonesia saat ini, pengembangan perekonomian lebih difokuskan untuk efisiensi investasi yang tercermin dalam visi pembangunan di tahun 2020. Hal ini tentunya didasarkan pada tujuan konstitusional untuk menciptakan kesejahteraan serta kemakmuran masyarakat di Negara Indonesia (Lestari et al., 2018; Rahadiyan, 2014), nilai-nilainya telah terkristalisasi dalam amanat Pasal33 UUD NRI 1945 sebagai konstitusi Negara Indonesia.

Adanya amanat kontitusional tersebut memberikan konsekuensi-logis bagi negara untuk menyelenggarakan perekonomian yang sejalan dengan paradigma demokrasi ekonomi Indonesia (Utama, 2018). Salah satu upaya negara untuk menjalankan amanah dengan sebaikbaiknya adalah dengan memberikan diversifikasi peran melalui pembangunan usaha pada sektor publik. Sehingga negara yang diwakili oleh pemerintah dapat memiliki peran ganda dengan menjadi otoritas di sektor publik (jure imperi) yang bertugas untuk menyelenggarakan pemerintahan eksekutif dan pelayanan terhadap masyarakat (public service), dan juga menjadi pelaku ekonomi di sektor privat (jure gestionis) yang bertugas untukmenyelenggarakan perekonomian di bidang privat dan mencari keuntungan untukpendapatan negara (Ansari, 2019; Huda, 1996). Melalui usaha di sektor privat inilah, tercipta sebuah konsep perusahaan berbadan hukum PerseroanTerbatas (PT) yang dimiliki oleh negara, perusahaan tersebut dikenal dengan nama BUMN atau BadanUsaha MilikNegara.

Istilah BUMN di Indonesia merupakan perusahaan yang dimiliki serta dikelola oleh negara untuk mencari pendapatan dan keuntungan bagi negara (State Owned Enterprise/ 
SOEs). Perusahaan ini berperan sangat penting dalam memegang dan menyelenggarrakan perekonomian negara (Harris, 2017; Rahadiyan, 2014). Peran BUMN dibutuhkan dalam perekonomian nasional, karenaBUMN sangat berdampak dalam memberikan kontribusiterhadap pemasukan atau penerimaan kas keuangan negara dalam bentuk deviden. Selain itu, perusahaan ini memiliki peran strategis terhadapproduksi barang dan jasa kepada masyarakat yang nantinya dapat memberikan keseimbangan terhadap sektor swasta yang turut mengembangkan perekonomian nasional (Pramagitha \& Sukranatha, 2019).

Secara definitif BUMN telah diatur dan termaktub dalam Undang-Undang Nomor 19 Tahun 2003 tentang Badan Usaha Milik Negara (UU BUMN). Pasal 1 angka 1 UU BUMN menyatakan bahwa BUMN merupakan suatu badan usaha yang keseluruhan ataupun sebagian besarmodal badan usaha dimiliki oleh Negara Indonesia dengan cara penyertaan modal oleh negara (kekayaan negara yangdipisahkan) secara langsung. Artinya, negara dalam hal ini memutuskan untuk memberikan modal atau pendanaan dari Anggaran Pendapatan Belanja Negara (APBN) kepada perusahaan. Maka hakikatnya penyertaan modal tersebut lepas dari APBN Negara Indonesia yang mana negara hanya sebatas berkedudukan sebagai pemegang saham perusahaan (Rimardhani et al., 2016).

Saat menjalankan operasional perusahaan, BUMN sebagai subjek hukum wajib berbentuk badan hukum atau yang dikenal dengan penyebutan "recht persoon", sama hal nya dengan "natuurlijk person" yaitu orang sebagai subjek hukum. BUMN sebagai subjek hukum juga mempunyai hak serta kewajiban atau duty. Perusahaan dengan bentuk BUMN dinilai cakap hukum yang mana BUMN dapat melakukan perbuatan-perbuatan hukum terhadap subjek-subjek hukum lain. Akan tetapi, perbuatan hukum yang dapat dilakukan olehBUMN terbatas pada perbuatan-perbuatan yang hanya berurusan dengan harta keekayaan milik BUMN sendiri, contohnya berupa pemembuatan perjanjian bisnis dengan subjek hukum lainnya (perusahan/orang). BUMN sebagai recht person, dibentuk melalui proses hukum yang tidak fiktif (nyata), hal ini ditandai dengan BUMN dapat melakukan kegiatan operasional bisnisnya di masyarakat (Harahap, 2011). Proses menjalankan hak serta kewajibannya, BUMN harus dikelola/dijalankan oleh organ-organnya. Organ-organ dalam BUMN dapat berupa RUPS (Rapat Umum PemegangSaham), Direksi BUMN serta Komisaris BUMN itu sendiri. Masing-masing organ tersebut memeiliki tugas serta kewewenanganya masing- 
masing yang telah ditetapkan dalam Anggaran Dasar Rumah Tangga (ADRT) dan UU BUMN (Kurniawan, 2012).

BUMN sebagai recht person tidak mampu melakukan perbuatan hukum tanpa bantuan organ-organ didalamnya. Walaupun demikian, BUMN memiliki kedudukan atau status yang bersifat mandiri atau persona standi judicio (Prasetya, 2011). Hal ini dikarenakan BUMN sebagai entitas hukum atau legal entity memiliki kepengurusan serta kepemilikan yang terpisah dari pemiliknya (separate legal entity). Selain penyelenggaraan BUMN yang separate legal entity, tangung jawab yang dimiliki oleh BUMN memiliki sifat yang terbatas (limited liability/beperkte aanspraakelijkheid). Secara harfiah, eksistensi serta validitas sebuah BUMM yang berbadan hukum Perseroan Terbatas tidak terancam oleh kepailitan yang diakibatkan pengunduran pemilik atau pemegang saham karena BUMN memiliki kepengurusan serta kepemilikan yang terpisah dari pemiliknya (separate legal entity) (Isfardiyana, 2017).

Sejalan amanat Pasal 3 Undang-Undang Nomor 40 Tahun 2007 tentang Perseroan Terbatas (UU PT) pemegang saham memiliki tanggugjawab secara terbatas yang mana tanggungjawab pemegang saham hanya padamodal atau sahamyang dimilikinya. Berkaca pada Pasal tersebut maka pemegang saham tidak dapat dipertanggungjawabkan secara pribadi apabila terjadi kerugian yang dialami oleh perusahaan. Pertanggungjawaban terbatas ini sejalan dengan konsep BUMN yang dianut Negara Indonesia yaitu separate legal entity (Atikah, 2016). Hakikatnya, segala perbuatan hukum yang dilakukan oleh BUMN dengan subjek-subjek hukum yang lain adalah merupakan tanggung jawab pribadi BUMN itu sendiri. Maka dari itu, pemegang saham BUMN tidak mempunyai hak bahkan kewajiban hukum atas setiap perbuatan hukum yang dilakukanBUMN. Atas dasar hal tersebut, setiap keuntungan yang diperoleh BUMN melalui perbuatan hukumnya merupakan keuntungan BUMN, begitupun sebaliknya yang mana BUMN mengalami kerugian, maka kerugian tersebut adalah beban dan tanggung jawab BUMN itu sendiri (Rahadiyan, 2014).

BUMN yang berbadan hukumkan Perseroan Terbatas merupakan manifestasi artificial person/ kunsmatige rechtspersoon yang tidak mampu melakukan perbuatan hukum tanpa adanya organ-organ pembantu (contohnya Direksi, Komisaris dan RUPS). Organ-organ yang kedudukannya sebagai pengurus nantinya bertanggung jawab, mewakili perusahaan dalam menjalankan urusannya, atau mengambil keputusan atas nama BUMN. Organ-organ tersebut masing-masing memiliki tugasnya serta kewenangan untuk mengurusi BUMN (Akbar, 2016). 
Berkaca pada Pasal 1 angka 5 UU PT bahwa Direksi merupakan salah satu organ fundamental dalam BUMN diberikan tugas dan kewenangan untuk menjalankan kepengurusan BUMN dan bertindak menjadi wakil atas nama BUMN, baik bertindak di dalam maupun diluar pengadilan demi kepentingan BUMN sesuai dengan ketentuan ADRT perushaan.

Saat menjalankan pengurusan sebagai organ BUMN, Direksi melaksanakan pengurusan perusahaan melalui sebuah kepercayaan (fiduciary duty) yang diberikan melalui prosedur RUPS oleh para pemegang saham (shareholders). Fiduciary duty menjadi prinsip dasar Direksi dalam menjalankan amanah sebaik-baiknya dengan harapan besar memiliki intregritas, intelektualitas, itikad baik, profesionalisme, dan kecakapam dalam pengurusan BUMN. Sehingga diharapkan nantinya dapat menjalankan operasional BUMN secara berkesinambungan (continuity) dan menciptakan keuntungan (profitability) (Khairandy, 2009).

Namun, dalam menjalankan tugas danfungsinya Direksi kerap kali menghadapi tantangan dianggap telah memberikan keputusan yang merugikan yang berujung pada proses peradilan pidana (criminal legal procedure). Kriminalisasi Direksi ini seringkali terjadi diakibatkan adanya suatu keputusan Direksi yang mampu menciptakan kerugian bagi BUMN dan dengan kerugian tersebut, Direksi dianggap telah menciptakan kerugian pula terhadap APBN yang dileburkan kedalam perusahaan melalui penyertaan modal langsung oleh negara (Mahyani, 2019).

Kriminalisasi Direksi pernah dialami oleh Mantan Direktur Utama PT. Pertamina (BUMN) yakni Karen Agustiawan yang dianggap melakukan tindak pidana korupsi (Tipikor) oleh pemegang saham akibat keputusan bisnis yangdimabilnya (business decision). Karen dianggap telah melanggar ketentuan Pasal 3 ayat 1 Undang-UndangNomor 31 Tahun 1999 sebagaimana diubah dalam Undang-Undang Nomor 20 Tahun 2001 tentang Pemberantasan Tindak Pidana Korupsi jo. Pasal 55 ayat 1 ke-1 KUHP. Keputusan bisnis Karen atas nama PT. Pertamina dengan Roc Roil Ltd dalam proyek Participacing Interest (PI) Blok Buster Manta Gummy(BMG) dianggap telah menguntungkan Roc Roil Ltd. Menurut perhitungan laporan dari Kantor Akuntan Publik Drs. Soewarno, perbuatan Karen Agustiawan telah merugikan APBN sebesar Rp. 568.000.000.000.000 (Gabrilin, 2019).

Dalam melaksanakan operasi bisnis BUMN tidak selamanya dihadapkan pada keuntungan semata, melainkan juga dihadapkan pada fase-fase kerugian. Akan tetapi, setiap 
kerugian yang ditimbulkan akibat keputusan Direksi tidak dapat serta merta dikategorisasikan sebagai kejahatan berbasis ekonomidengan pelaku terpelajar (white collar crime) (Atmasasmita, 2010). Selain itu, Direksi tidak dapat dimintakan pertanggungjawaban pidana akibat kesalahan terhadap pengambilan keputusan bisnisnya (mere error of judgement) (Fuady, 2010). Akan tetapi diperlukan adanya suatu identifikasi dan pembuktian (bewijs) bahwa Direksi benar-benar berbuat kesalahan (schuld) yang disertai niat jahat (mens rea), kelalaian, tidak beritikad baik dan bertentangan dengan doktrin business judgement rule atau prinsip-prinsip bisnis yang layak. Berdasarkan paparan yang diuraikan diatas, penelitian ini akan berfokus pada penerapan business judgement rule doctrine sebagai perlindungan hukum terhadap Direksi dalam memberikan keputusan bisnis pasca Putusan Mahkamah Konstritusi Republik Indonesia (MK RI) No. 48/PUU-XI/2013 dan 62/PUU-XI/2013.

\section{METODE PENELITIAN}

Penelitian ini bersifat deskriptif dengan jenis penelitian yuridis normatif. Jenis pendekatan yang digunakan adalah pendekatan peraturan perundang-undangan (statue approach) dan pendekatan konseptual (conseptual approach). Pendekatan perundangundangan merupakan pendekatan yang mengacu pada ketentuan peraturan perundangundangan seperti UU BUMN, UU PT, dan Undang-UndangNomor 1 Tahun 2004 tentang Pembendaharaan Negara (UU Pembendaharaan Negara) serta peraturan-peraturan lainnya yang berkaitan. Pendekatan konseptual merupakan pendekatan yang digunakan untuk memahami teori dan konsep-konsep yang dapat dijadikan landasan penelitian ini. Data yang digunakan pada penelitian ini adalah data sekunder yang terbagi atas bahan hukum primer, bahan hukum sekunder, dan bahan hukum tersier. Data sekunder tersebut diperoleh melalui teknik pengumpulan studi kepustakaan (library research), yang kemudian data dianalisis secara kualitatif (Marzuki, 2009).

\section{HASIL DAN PEMBAHASAN}

Pengaturan Business Judgement Rule Terhadap Penyelenggaraan BUMN dalam Ketentuan Hukum di Indonesia

BUMN memiliki kemandirian dalam menjalankan kepengurusannya secara independen. BUMN yang berstatus badan hukum (recht person) memiliki hak serta kewajiban dan memiliki kecakapan hukum dalam melakukan perbuatan-perbuatan hukumnya. Bentuk badan hukum BUMN yang berupa Perseroan Terbatas ini bersifat terbuka dalam penanaman 
dan pembiayaan yang berupa modal (go public) sehingga BUMN memiliki kapasitas dan kewenangan untuk mengurus harta kekyaannya secara mandiri (Larry, 1984). Atas dasar konsep kemandirian BUMN yang berbadan hukum Perseroan Terbatas maka sangat jelas diperlihatkan bahwa BUMN telah mendapatkan pengakuan secara yuridis melalui UU PT atas status kemandiriannya sebagai suatu recht person atau badan hukum.

Pengaturan BUMN diatur dalam ketentuan undang-undang yang saling berkaitan, diantaranya adalah UU PT yang menjleaskan mengenai kemandirian perusahaan BUMN yang berstatus badan hukum dan bersifat mandiri. Selain itu, BUMN juga diatur secara khusus dalam UU BUMN yang mengatur mengenai pemberlakuan segala ketentuandan prinsipprinsip perusahaan milik negara.

Secara definitif berdasarkan Pasal 1 UU BUMN, menyatakan bahwa BUMN adalah badan usaha yang sebagian besar atau keseluruhan modalnya dimiliki oleh Negara Indonesia, yang mana penyertaan modalnya dilakukan secara langsung dan bersumber dari APBN yang dipisahkan. APBN yang dipisahkan tersebut merupakan kekayaan negara yang dijadikan sebagai penyertaan modal oleh negara pada perusahaan persero dan/atau perum. Sementara pemisahan keuangan negara adalah pemisahan kekayaan negara dari APBN untuk dijadikan penyertaan modal negara pada BUMN yang selanjutnya pembinaan dan pengelolaan keuangan tersebut tidak lagi didasarkan pada system APBN. Namun pembinaan dan pengelolaannya didasarkan pada prinsip perusahaan yang sehat (Dwidjowijoto, 2003; Kusmono, 2016; Susanto, 2017). Meninjau Pasal 1 UU BUMN ini maka terlihat beberapa unsur bagi perusahaan agar dapat disebut sebagai BUMN yakni modal perusahaan tersabut wajib didominasi oleh negera, yang mana kepemilikan modal minimumnya adalah 51\%, kemudian penyertaan modal oleh negara tersebut berasal dari APBN yang dipisahkan (Rahadiyan, 2014).

Saat BUMN melaksanakan kewajibannya untuk beroperasi, tentu BUMN tidak dapat menjalankannya secara langsung. Terdapat organ-organ kepengurusan yang nantinya mewakili BUMN untuk melakukan tindakan atau perbuatan-perbuatan hukum BUMN, salah satunya dilakukan oleh Direksi. Pasal 1 angka 5 UU PT menyatakan bahwa Direksi mempunyai tugas untuk melakakukan pengurusan terhadap Perseroan, untuk kepetingan Perseroan sesuai dengan maksud dan tujuan Perseroan serta mewakili Perseroan (Azheri \& Anggunsuri, 2020). 
Direksi dalam menjalankan tugas dan tanggung jawabnya memiliki dua fungsi yaitu fungsi pengurusan (management) serta fungsi perwakilan (representation). Kedua fungsi tersebut, pada dasarnya telah termaktub dalam ADRT. Direksi BUMN yang mempunyai kekuasaan (power), berwenang (authority) serta bertanggungjawab (responsibility) penuh atas pengurusan BUMN (Sjawie, 2017). Akan tetapi, dalam melaksanakan segala kewajibannya Direksi Perseroan BUMN selayaknya diberikan hak imunitas yang sesuai koridor peraturan perudang-undangan agar dapat menjalankan tugas dengan optimal terutama saat melakukan keputusan bisnisnya (business decisions). Perlindungan hukum Direksi tersebut dikenal dalam hukum Perseroan sebagai Business Judgement Rule. Secara definitif Business Judgement Rule diinterpretasikan bahwa Direksi tidak dapat dipertanggunngjawabkan atas kerugian yang ditimbulkan dari suatu pengambilan keputusan bisnis oleh Direksi (Kusmono, 2016), akan tetapi tindakan tersebut harus didasarkan pada itikad baik dan kehati-hatian agar Direksi bisa mendapat perlindunganhukum tanpa perlu mendapatkan pembenaran dari shareholders (pemegang saham) ataupun pengadilan atas keputusan bisnis yang diambilnya terhadap penyelenggaraan perusahaan (Nasution et al., 2016; Subekti, 2008). Sehingga Direksi mendapatkan job protection saat menjalankan kewajiban untuk mengurus perusahaan dan nantinya diharapkan mampu bekerja secara optimal untuk mewujudkan prinsip-prinsip good corporate governance atau prinsip-prinsip pengelolaan perusahaanyang baik (Rimardhani et al., 2016).

Jika ditinjau dalam ketentuan hukum di Indonesia, doktrin Business Judgement Rule telah termanifestasi ke dalam UU PT yang mengatur berkenaan dengan tugas dan imunitas seorang Direksi perusahaan. Hal ini tercermin pada Pasal 92 UU PT, menyatakan bahwa :

1) Seorang Direksi perusahaan wajib melaksanakan pengurusan perusahaan demi kepenetingan perusahaan yang sesuai denganADRT perusahaan;

2) Seorang Direksi diberikan kewenangan untuk melaksanan pengurusan perusahaan, sejalan dengan ketentuan/kebijakan yang dianggap patut dalam batas ketentuan peraturan perundang-undangan danADRT perusahaan;

3) Seorang Direksi harus melaksanakan pengurusaan perusahaan secara bertanggung jawab (responsibility) serat penuh itikad baik atau good faith;

4) Seorang Direksi dapat diperpertanggungjawabkan seluruhnya secarapribadi ataskerugian perusahaan, manakala telahlalai dalam melaksanakan tugasnya; 
5) SeorangDireksi tidakdapat dipertanggungjawabkan atas segala kerugian perusahaan manakala mampu membuktikan:

a. Kerugian perusahaan tidak ditimbulakan oleh kelalaian Direksi dalam menjalankan tugasnya;

b. Telah menjalankan kepengurusan perusahaan secara hati-hati dengan penuh itikad baik demi kepentingan perusahaan serta sesuai denganADRT perusahaan;

c. Tidak adanya conflict of interest atau benturan kepentingan atas tindakan penyelenggaran perusahaan secaralangsung maupun tidaklangsung yang menciptakan kerugian; dan

d. Telah melakukan perbuatan pencegahan (preventif) untuk meminimalisasi bahkan mencegah timbulnya kerugian yang dialami oleh perusahaan.

Dalam hal ini dapat diambil benang merah terkait norma yang berkaitan dengan business judgement rule doctrine. Pertama, bahwa Direksi dalam menjalankan segala kewajiban pengurusan harus didasarkan pada tujuan dan kepentingan Perseroanyang ditentukan oleh undang-undang atau ADRT Perseroan. Hal ini dikarenakan Direksi merupakan jabatan yang diberikan atas kepercayaan melalui RUPS (fiduciary duty). Sehingga dalam menjalankan segala kewajibannya Direksi perusahaan harus melaksanakan sesuai dengan kepentingan dan kebutuhan Pereroan yang tertuang dalam ADRT dan dilaksanakan secara itikad baik atau good faith, penuh tanggungjawab dan menggunakan prinsip kehatihatian (prudent) terutama dalam mengeluarkan sebuah keputusan bisnis (business decisions) agar tidak mengalami kesalahan atau kerugian yang fatal.

Kedua, setiap Direksi dalam menjalankan kewajibannya bisa dipertanggungjawabkan secara personal ataskerugian perusahaan yang dihasilkan, manakala dalam melaksanakan kepengurusan, Direksi perusahaa melakukan kesalahan (mistake) serta kelalaian (negelence) yang didasarkan pada perbuatan yang tidak beritikad baik maupun prinsip kehati-hatian. Jika dalam organ Direksi terdapat dua Direksi atau lebih, maka ia akan dipertanggungjawabkan secara tanggung renteng.

Ketiga, dalam melaksanakan kewajiban kepengurusannya, Direksi memiliki hak imunitas agar dapat terlepas dari kriminalisasi dari kerugian perusahaan dan terhindar pertanggungjawaban pidana kerugian perusahaan. Hak imuninitas ini berlaku jikaDireksi perusahaan telah memenuhi beberapa unsur, diantaranya: 1). Kerugian perusahaan tidak 
didasarkan/berasal dari kesalahan (mistake) ataupun kelalaian (negelence)Direksi dalam mengambil keputusan bisnisnya; 2). Telah menerapkan itikad baik (good faith) serta prinsip kehati-hatian (prudent) dalam menyelenggarakan perusahaan; 3). Tidak memiliki conflict of interest atas tindakan penyelenggaraan perusahaan yang baik langsung ataupun tidak langsung; dan 4). Telah melakukan pencegahan serta upaya preventif lainnya dalam menanggulangi timbulnya kerugian pada perusahaan. Maka dari itu, manakala Direksi BUMN telah memenuhi 4 (empat) unsur diatas, maka Direksi BUMN tidak bisa dimintakan pertanggungjawaban terhadap kerugian yang diakibatakan oleh keputusan bisnisnya, baik pertanggungjawaban secara pidana maupun secara perdata.

\section{Perlindungan Hukum Keputusan Bisnis Direksi BUMN Melalui Business Judgement Rule} Doctrine Pasca Putusan Mahkamah Konstitusi No. 48//PUU-XI/2013 \& No. 62/PUU$X I / 2013$

Direksi BUMN saat menjalanakan kepengurusan perusahaan dan saat mengambil keputusan bisnis (business decisions) harus didasarkan pada prinsip kehati-hatian (prudent) serta adanya itikad baik atau good faith, dan kesesuaian dengan ADRT perusahaan serta peraturan perundang-undangan. Keputusan bisnis dari Direksi BUMN yang dibuat berdasarkan prinsip kepercayaan (fiduciary duty) tidak dapat dimintakan pertanggungjawaban secara pribadi manakala terjadi kerugianBUMN (Wijaya, 2019). Manakala terbukti keputusan tersebut melanggar prinsip fiduciary duty, Direksi harus mempertanggungjawabkan akibat dari keputusan tersebut secara pribadi. Hal ini merupakan manifestasi dari hak imunitas terbatas Direksi BUMN yang memiliki tanggungjawab besar terhadap keberlangsungan perusahaan yang diberikan oleh para anggota RUPS (Isfardiyana, 2007).

Secara etimologi prinsip fiduciary duty berasaldari Bahasa Inggris yaitu "fiduciary" serta berasal dari Bahasa Latin yaitu “fiduciaries” yang keduannya mempunyai arti yang sama yaitu "kepercayaan” atau bermakna mempercayai. Sedangkan kata "duty” mamiliki arti “tugas” dalam Bahasa Inggris (Harahap, 2011). Seseorang dapat dikatakan memiliki fiduciary duty setelah seorang tersebut telah memiliki/mempunyai kapasitas kepercayaan yang diperoleh ketika pemilik usaha/perusahaan mempercayakan perusahaan serta kepentingannya kepada orang tersebut. Sehingga, seseorang yang mendapatkan kepercayaan tersebut wajib melaksanakan tugas dan kewajibannya dalam menyelenggarakan perusahaan berdasarkan 
prinsip kehat-hatian dan high degree of good faith atau iktikad baik yang tinggi (Harahap, 2011; Rahadiyan, 2014).

Kepercayaan dalam menjalankan tugas dan kewajiban perusahaan, akan terbentuk dari adanya fiduciary relation (hubungan kepercayaan) yang baik antara pemilik perusahaan dengan orang-orang yang nantinya dipercayakan untuk mengelola perusahaan (organ perusahaan). Fiduciary relation tercipta dari adanya hubungan/relasi antara dua belah pihak yang memiliki kepentingan, yakni pihak beneficiary (penerima kepercayaan) dan pemberi kepercayaan (fiduciay). Pihak beneficiary adalah pihak yang memiliki tanggungjawab dan kewajiban dalam bertindak atau memberikan nasihat kepada pihak pemberi kerpercayaan bagi kepentingan pihak pemberi kepercayaan, yang tentunya berkaitan dengan permasalahanpermasalahn bisnis atau kerjasama bisnis. Maka, fiduciary duty dapat dikatakan sebagai tugas dan tanggung jawab beneficiary yang terbentuk dari adanya "trust" atau kepercayan dari fiduciay. Dalam konteks menjalankan BUMN, fiduciary duty yang diberikan kepada beneficiary dalam hal ini adalah Direksi BUMN, mengharuskan Direksi tesebut mempunyai duty of care and skill atau kepedulian serta kemampuan, good faith, loyality serta kejujuran atau honestly terhadap pengelolaan BUMN. Dapat dikatakan bahwan Direksi BUMN dalam menjalakan tugas dan kewajibannya secara hati-hati serat tidak boleh lalai dalam menjalankan aktivitas bisnis BUMN (Putra \& Kasih, 2013).

Implementasi prinsip fiduciary duty oleh Direksi BUMN dalam menjalankan tugasnya, diwajibkan memuat klasifikasi sebagai berikut: 1). Wajib melaksanakan tugas secara itikad baik (good faith); 2). Bersikap jujur (honest); 3). Memiliki kompetensi dan keilmuan yang sesuai dan dapat dipertanggungjawabkan; 4). Memiliki kepedulian yang tinggi terhadap perusahaan (duty of care); dan 5). Mempunyai loyality atau loyalitas yang tinggi yang bidang pekerjaan. Kemudian dalam menjalankan tugasnya, seorang Direksi BUMN memiliki kewajiban sebagai berikut:

\section{Duty of care atau prudential duty}

Merupakan prinsip yang wajib diimplementasikan oleh Direksi BUMN agar seorang Direksi tidak bertindak secara lalai dan semeberono (carelessly dan neglegence) dalam menjalankan tanggungjawab dan kewajiban BUMN. Direksi BUMN dalam mengambil suatu kebijakan serta pengelolaan perusahaan wajib didasarkan pada prinsip kehati-hatian dan itikad baik, selain itu penyelenggaraan BUMN dilakukan oleh Direksi denagn 
memperhatikan pengetahuan serta pengalaman yang dimiliki. Untuk itu, Direksi BUMN wajib memperhitungkan atau memperkirakan serta memperhatikan segala risiko-resiko yang nanntinya dapat terjadi akibat pengambilan kebijakannya. Dalam mengambil keputusan atau kebijakan yang baik dan tepat, seorang Direksi BUMN diharuskan melaksanakan sesuai standard of care atau kriteria kepedulian tertentu agar kewajiban implementasi prinsip duty of care idapat terpenuhi. Adapun kriteria kepedulian tersebut adalah sebagai berikut (Isfardiyana, 2017; Sjawie, 2017):

a. Selalu menjalankan secara itikad baik (good faith);

b. Segala tugas-tugas harus dilaksanakan dengan penuh kepedulian serta kehati-hatian selayaknya mengelola bisnis atau usaha milik pribadi;

c. Seluruh tugasyang diberikan dilakukan dengan cara atau mekanisme yang terpercaya secara logis atau reasonably believe dan cara yang dimabil merupakan pilihan yang terbaik atau best interest bagi perushaan yang dikelola.

\section{Duty to Disclosure}

Duty to Disclosure merupakan sikap yang harus dimiliki oleh Direksi BUMN dengan memberikan validitas atas informasi-informais perusahaan kepada stakeholders atau semua pihak yang berkepentingan dengan perusahaan dan berdasarkan tujuan untuk menjamin informasi berdasarkan prosedur yangtransparan dan akuntabel. Sehingga dapat dipertanggungjawabkan dan dievaluasi secara berkala oleh pihak pemberi kepercayaan.

3. Duty of Loyality

Prinsip ini adalah sikap loyalitas Direksi BUMN dalam melaksanakan segala tanggugjawab dan kewajiban yang diberikan, serta mengabdikan diri terhadap perusahaan yang ia kelola. Prinsip ini juga menuntut Direksi BUMN untuk patuh dan setia terhadap perusahaan, mengamanatkanbest interest bagi perusahaan serta kepentingan pemegang sahamnya harus prioritaskan daripada semua kepentingan yang dimiliki oleh Direksi BUMN. Sehingga, dalam secara praktik prinsip loyalitas, seorang direksi tidak boleh memiliki konflik kepentingan antara kepentingan pribadinya dengan kepentingan perusahaan dalam memperoleh keuntungan.

4. Duty of Skill

Duty of Skill merupakan prinsip yang menuntut bahwa Direksi BUMN haruslah seseorang yang profesional, karena Direksi BUMN diharapkan dapat membawa perusahaan pada kemajuan. Disamping itu, keahlian tersebut juga digunakan untuk melindungi dirinya 
sendiri. Apabila direksi tidak memiliki keahlian dan kemampuan dalam mengelola perusahaan, maka dimungkinkan kerugian perusahaan akan menjadi tanggungjawab pribadinya.

\section{Duty of Diligence}

Prinsip ini merupakan bagian dari prinsip fiduciary duty yang mana memuat ketentuan bahwa seorang Direksi BUMN diwajibkan untuk rajin dan giat dalam melaksanakan tugas tanggungjawab dan kewajiban kepengurusannya dalam mengegelola aktivitas bisnis perusahaan.

\section{Duty of Act Lawfully}

Duty of Act Lawfully merupakan prinsip kepercayaan yang diberikan kepada perusahaan bukanlah kepercayaan tanpa batas dengan kewenangantanpa batas. Tetapi, Direksi dalam melakukan segala kepengurusannta didasarkan dan dibatasi oleh ketentuan peraturan perundang-undangan yang ada dan sesuai ADRT PT.

Direksi BUMN dalam menjalankan kewajiban dan tanggung jawab tentunya juga tidak lepas akan hambatan maupun tantangan yang dihadapinya. Salah satunya mengenai kriminalisasi keputusan bisnis Direksi BUMN yang dianggap merugikan kekayaan negara atau dalam hal ini merupakan APBN. Hal ini terjadi dalam kasus yang dialami oleh Karen Agustiawan seorang Mantan Direktur Utama PT. Pertamina. Karen Agustiawan ditetapkan sebagai tersangka dalam perkara dugaan kasus tindak pidana korupsi oleh Kejaksaan Agung Republik Indonesia (Kejagung RI). Karen Agustiawan diduga terlibat dalam tindakan penyimpangan investasi aset perusahaan minyak asing yang bernama ROC Oil Company Ltd. Karen selaku Direksi BUMN (PT. Pertamina) mengambil keputusan bisnis dengan membeli sebagian aset perusahaanROC Oil Company Ltd. Aset tersebut terletak di Australia tepatnya di lapangan eksplorasi BaskerManta Gummy (BMG). Kedua perusahaan menyepakati pembelian aset tersebut dengan jumlah harga sebesar US\$ 31,9 juta. Akan tetapi, pengembilan keputusan bisnis Karen Agustiawan untuk membeli aset tersebut diniali tidak memberikan profit (keuntungan) kepada BUMN yang dikelolanya yakni PT. Pertamina. Dengan ketidaktepatan Karen Agustiawan dalam mengambil keputusan bisnis tersebut, justru mengakibatkan BUMN (PT. Pertamina) merugi, kerugian tersebut ditaksir sebesar Rp. 568.000.000. 000.000 (Putranto, 2018). 
Pada vonnies tuntutan Karen Agustiawan dalam putusan Pengadilan Negeri Jakarta Pusat (PN Jakpus) No. 15/Pid.Sus-TPK/2019/PN.JKT menyatakan bahwa Karen Agustiawan telah terbukti dan meyakinkan (negative wettelijk bewijstheorie) melakukan tindak pidan korupsi. Sehingga Karen Agustiawan dikenakan sanksi pidana penjara selama 8 (delapan) tahun dan pidanadenda sejumlah Rp. 1.000.000.000,00. Putusan tersebut juga diperkuat dalam putusan Pengadilan Tinggi DKI Jakarta (PT DKI Jakarta) No. 34/Pid.Sus-TPK/2019/PT.DKI bahwa Karen Agustiawan juga terbukti dan meyakinkan telah melakukan tindak pidana korupsi melalui pengambilan keputusan bisnis yang menciptakan kerugian terhadap keuangan negara (kerugian BUMN). Karen Agustiawan dianggap didakwa telah melanggar Pasal 2 ayat 1 Undang-UndangNomor 20 Tahun2001 tentang Perubahan Atas Undang-Undang Nomor 31 Tahun 1999tentang TindakPidana Korupsi juncto Pasal 55 ayat 1 KUHP. Namun, pada pemeriksaan tingkat Mahkamah Agung (judex juris), Mahkamah Agung mengoreksi putusan sebelumnya dan memutuskan sebaliknya yang mana Mahkamah Agung menyatakan Karen selaku Direksi BUMN PT. Pertamina tidaklah terbukti secara sah dan meyakinkan dalam melakukan tindak pidana korupsi, serta Mahkamah Agung juga mamutuskan Karen Agustiwan bebas dari segala tuntutan hukum pidana terkait korupsi. Mahkamah Agung berpendapat dalam ratio decidendi (pertimbangan hakim) dalam putusannya bahwa keputusan bisnis yang diambil oleh Karen Agustiawan selaku Direksi PT. Pertamina masih dalam koridor ketentuan hukum yang berlaku berdasarkan prinsip-prinsip bisnis yang layak atau yang biasa dikenal business judgment rule doctrine. Oleh karena itu, sangat begitu tidak tepat manakala Karen Agustiawan selaku Direksi PT. Pertamina dituntut tindak pidana korupsi dikarenakan telah mengambil keputusan bisnis yang telah merugikan PT. Pertamanina itu sendiri.

Kriminalisasi atas pengambilan keputusan bisnis oleh Karen Agustiawan dinilai tidak tepat, namun kriminalisasi ini hadir karena adanya benturan konsep norma mengenai pemaknaan “kekayaan negara yang dipisahkan” antara UU BUMN, UU PT dan UU Pembendaharaan Negara. Konsep kekayaan negara yang dipisahkan yang terdapat pada UU BUMN telah diatur dalam Pasal 1 yang mana menyatakan bahwa badan usaha (perusahaan) seluruh atau sebagaian modal yang dimiliki oleh negara tersebut bersumber dari kekayaan negara yang terpisah. Hal ini berarti bahwa biaya yang dikeluarkan oleh negara melalui penyertaan modal secara langsung dari APBN bukan lagi menjadi kekayaan negara, karena 
sejatinya modal tersebut sudah terbagi atas saham-saham, obligasi, atau surat berharga lainnya sebagai kekayaan negara yang dipisahkan (Lestari et al., 2018; Susanto, 2017).

Kemudian konsep kekayaan negara yang dipisahkan yang terdapat pada UU PT termaktub dalam Pasal 3 ayat (1) yang menyatakan bahwa pemegang saham perusahaan (shareholders) tidak memiliki tanggungjawab secara perseorangan manakala perjanjian yang disepakati atas nama perusahaan mengamali kerugian. Melainkan, pemegang saham hanya bertanggungjawab atas saham yang dimiliki atau tidak melebihi dari saham yang dimilikinya. Maka dari itu, apabila bercermin pada pengelolaan BUMN yang mana negara dikategorikan sebagai pemegang saham, maka negara hanya bertanggung jawab atas saham yang ada pada BUMN itu sendiri. Pasal 3 ayat (1) ini merupakan konsep dari kepemilikan perusahaan dengan prinsip entitas yang terpisah (separate legal entity) serta tanggung jawab hukum secara terbatas (limited liability).

Sedangkan konsep kekayaan negara yang dipisahkan yang terdapat pada UU Pembendaharaan Negara tercermin pada Pasal 1 angka 22 yang menyatakan kerugian negara merupakan berkurangnya uang, surat berharga, maupun barang milik negara secara nyata dan pastijumlahnya yang diakibatkan oleh perbuatan melawan hukum baik sengaja maupun lalai. Atas hal tersebut, banyak sekali timbul kerancuhan mengenai konsep penormaan perbedaan antara kekayaan negara dengan kekayaan perusahaan (Ghinarahmatina, 2018).

Mengacu pada Putusan Mahkamah Konstitusi No. 48/PUU-XI/2013 serta No. 62/PUU-XI/2013 telah menetapkan bahwa status kekayaan negara pada perusahaan yang bersumber dari keuangan negara yang terpisah dari APBN untuk disertakan menjadi penyertaan modal di BUMN, merupakan bagian dari keuangan negara. Penetapan ini juga selaras dengan Teori Sumber, yang mana teori klasik ini menyatakan serta menegaskan bahwa setiap aliran keuangan negara yang bersumber dari APBNharus dipertanggungjjawabkan berdasarrkan mekanisme pertanggungjawabanAPBN (Paputungan, 2018). Sehingga dapat ditarik benang merah, bahwa kerugian yang ditimbulkan oleh perusahaan BUMN yang mendapatkan penyertaan modal atau pendanaan dari kekayaan negara yang terpisah juga termasuk kerugian terhadap APBN yang harus ditanggung oleh negara.

Terdapat hal yang menjadi dasar setelah adanya Putusan MK No. 48/PUU-XI/2013 serta No. 62/PUU-XI/2013 yang manna kerugian yang dialami oleh BUMN juga termasuk kerugian keuangan negara yang pertanggangungjawabannya didasarkan pada mekanisme 
peertanggungjawaban APBN. Namun, apabila kerugian yang dialami oleh BUMN akibat adanya keputusan bisnis oleh Direksi, maka Direksi tidak dapat dituntut atau dimintai pertanggungjawaban baik secara pidana maupun perdata. Dikarenakan perlu adanya pembuktian mengenai niat jahat (mensrea) dari Direksi dan kejahatan yang dilakukan (actus reus) atas keputusan bisnisnya. Selain itu juga perlu adanya pembuktian terhadap pemenuhan unsur-unsur kesalahan (schuld), kelalaian (negelence), dan perbuatan melawan hukum pidana (wedderechtrlijke daad). Maka dari itu, upaya perlindungan hukum yang diberikan kepada Direksi atas pengambilan keputusan bisnisnya berupa "hak imunitas” atau imunity right yang mempersyaratkan pengambilan keputusan bisnis tersebut telah memenuhi persyararan prinsipprinsip business judgement rule doctrine yang terkandung dalam Pasal 92 UU PT, sehingga Direksi dapat terlepas atau terhindar dari pertanggungjawaban pidana (criminal liability).

\section{KESIMPULAN}

Terdapat perubahan paradigma pasca Putusan MK No. 48/PUU-XI/2013 dan 62/PUUXI/2013 terhadap pemaknaan kekayaan negara yang dipisahkan dari sumber keuangan negara. Hal ini berpengaruh terhadap pertanggungjawaban seorang Direksi BUMN, yakni terkait pengambilan keputusan bisnis yang menciptakan kerugian terhadap BUMN. Pada dasarnya Direksi BUMN memiliki hak imunitas (imunity right) sehingga Direksi tidak dapat dimintakan pertanggungjawaban manakala pengambilan keputusan bisnis tersebut mengakibatkan kerugian terhadap BUMN. Namun, dalam penyelenggaraan serta pengambilan keputusan terhadap aktivitas bisnis BUMN, Direksi wajib melaksanakan dengan penuh penuh tanggung jawab (full of responsibility) serta iktikad baik yang tinggi (high degree good faith). Pertanggungjawaban tidak bisa dimintakan kepada Direksi BUM, jika hanya berdasarkan pada alasan ketidaktepatan dalam mengambil keputusan bisnis, tetapi pertanggungjwaban oleh Direksi BUMN ini harus dibuktikan terlebih dahulu apakah benar-benar telah melakuka kelalaian (negelence), tidak beriktikad baik, bertentangan dengan peraturan perudangundangan yang berlaku ataupun tidak menjalankan tugas serta wewenangnya dengan penuh tanggung jawab, sehingga menciptakan kerugian bagi BUMN.

Direksi BUMN dapat membuktikan bahwa ia tidak dapat dipertanggungjawabkan atas kerugian BUMN, dengan cara menjalankan segala tugas, tanggungjawab serta kewajibannya dengan benar dan tepat sesuai dengan prinsip business judgement rule atau prinsip bisnis yang layak yang termuat dalam Pasal 92 UU PT, sehingga seorang Direksi BUMN dapat terlepas 
dari pertangungjawaban pidana (criminal lialibility) akibat kerugian keuangan negara yang diakibatkan keputusan bisnisnya.

\section{DAFTAR PUSTAKA}

Akbar, M. G. G. (2016). Business JudgementRule SebagaiPerlindungan Hukum Bagi Direksi Perseroan Dalam Melakukan Transaksi Bisnis. Jurnal Justisi Ilmu Hukum, 1(1), 1-15. http://journal.ubpkarawang.ac.id/index.php/IlmuHukum/article/view/77

Ansari, M. I. (2019). ( The Role of the State-Owned Enterprises on Maritime Development ). Rechts Vinding, 8(1), 185-202. https://rechtsvinding.bphn.go.id/ejournal/index.php/jrv/article/view/315

Atikah, J. (2016). Kajian HukumTentang Kepemilikan Modal Terhadap Badan Usaha Milik Negara Menjadi Badan Usaha MilikSwasta. Lex Crimen, 5(3), 57-65. https://ejournal.unsrat.ac.id/index.php/lexcrimen/article/view/11681

Atmasasmita, R. (2010). Globalisasi dan Kejahatan Bisnis (Pertama). Kencana Prenada.

Azheri, B., \& Anggunsuri, U. (2020). The Implementation of Business Judgment Rule Principle in Managing the Company. 3(2), 32-44. https://doi.org/doi.org/10.25077/nalrev.v.3.i.2.p.32-44.2020

Dwidjowijoto, R. N. (2003). Analisa Privatisasi BUMN DiIndonesia. Jurnal Ilmu Sosial Dan Ilmu Politik, 6(3), 285-308. http://i-lib.ugm.ac.id/jurnal/detail.php?dataId=5210

Fuady, M. (2010). Doktrin-Doktrin Modern Dalam Corporate Law dan Eksistensinya dalam Hukum Indonesia (Kedua). PT. Citra Aditya Bakti.

Gabrilin, A. (2019). Mantan Dirut PertamninaKarenAgustiawan Divonis 8 Tahun Penjara. Kompas. $\quad$ https://nasional.kompas.com/read/2019/06/10/15393391/mantan-dirutpertamina-karen-agustiawan-divonis-8-tahun-penjara

Ghinarahmatina, A. (2018). Akibat Hukum Pemisahan Kekayaan Negara Melalui Penyertaan Modal. Lex Journal: Kajian Hukum \& Keadilan, 2(2), 1-18. https://doi.org/10.25139/lex.v2i2.1414

Harahap, M. Y. (2011). Hukum Perseroan Terbatas (kedua). Sinar Grafika.

Harris, F. (2017). Pemisahan Tanggung Jawab DireksiPerseroan Terbatas. Jurnal Hukum \& Pembangunan, 35(1), 87-104. https://doi.org/10.21143/jhp.vol35.no1.1457

Huda, N. (1996). PenerapanPrinsip Kekebalan Negara Terhadap Badan Usaha Milik Negara. Jurnal Hukum, 3, 28-34. https://doi.org/doi.org/10.20885/iustum.vol3.iss5.art4

Isfardiyana, S. H. (2007). Tanggung JawabDireksi Perseroan Terbatas dalam Pelanggaran Fiduciary. Padjajaran Jurnal Ilmu Hukum, 2(158), 168-191.

Isfardiyana, S. H. (2017). Business Judgement Rule Oleh Direksi Perseroan. Panorama Hukum, 2(1), 5-20. https://doi.org/https://doi.org/10.21067/jph.v2i1.1752

Khairandy, R. (2009). Perseroan Terbatas Doktrin, Peraturan Perundang-Undangan dan Yurisprudensi (revisi). Total Media. 
Kurniawan, M. (2012). Tanggung Jawab Direksi Dalam Kepailitan Perseroan Terbatas Berdasarkan Undang-Undang Perseroan Terbatas. Mimbar Hukum - Fakultas Hukum Universitas Gadjah Mada, 24(2), 213-225. https://doi.org/10.20303/jmh.v24i2.386

Kusmono. (2016). Pembelaan Melalui Prinsip-PrinsipBusiness JudgementRule Bagi Direksi Bumn Persero Bila Terjadi Kerugian. Jurnal Info Arta, 3, 33-42. https://doi.org/http://dx.doi.org/10.31092/jia.v3i0

Larry, D. S. (1984). TheLaw of Corporate Groups: Procedural Problemsin the Law of Parent and Subsidiary Corporations Philip I. Blumberg. Boston/Toronto: Little, Brown and Company, 1983. International Journal of Legal Information, 12(5-6), 268-269. https://doi.org/10.1017/S0731126500017959

Lestari, R., Ikhwansyah, I., \& Faisal, P. (2018). Konsistensi Pengukuhan Kedudukan Kekayaan Negara Yang Dipisahkan Pada Badan Usaha Milik Negara Menurut Pelaku Kekuasaan Kehakiman Dalam Kaitannya Dengan Doktrin Business Judgement Rule. Acta Diurnal Jurnal Ilmu Hukum Kenotariatan Dan Ke-PPAT-An, 1(2), 236. https://doi.org/10.24198/acta.v1i2.118

Mahyani, A. (2019). Tanggung Jawab Pidana Direksi Bumn Yang Merugi. Jurnal Hukum Bisnis Bonum Commune, 2(1), 1. https://doi.org/10.30996/jhbbc.v2i1.2309

Marzuki, P. M. (2009). Penelitian Hukum. Kencana.

Nasution, B., Siregar, M., \& Mulyadi, M. (2016). BusinessJudgement Rule DikaitkanDengan Tindak Pidana Korupsi Yang Dilakukan Oleh Direksi Badan Usaha Milik Negara Terhadap Keputusan Bisnis Yang Diambil. USU Law Journal, 4(1), 33-44. https://media.neliti.com/media/publications/14296-ID-business-judgement-ruledikaitkan-dengan-tindak-pidana-korupsi-yang-dilakukan-ol.pdf

Paputungan, M. (2018). Diskursus Kewenangan AuditBpk Terhadap Keuangan BUMN (PERSEROAN) Pasca Putusan MK Nomor 62/PUU-XI/2013. Mimbar Hukum - Fakultas Hukum Universitas Gadjah Mada, 29(3), 430-444. https://doi.org/10.22146/jmh.26884

Pramagitha, P. A., \& Sukranatha, A. A. K. (2019). Prinsip business judgment rule sebagai upaya perlindungan terhadap keputusan bisnis direksi bumn. Journal Ilmu Hukum, 7(12), 1-14. https://ojs.unud.ac.id/index.php/kerthasemaya/article/view/52055/30833

Prasetya, R. (2011). Perseroan Terbatas (Cetakan Pe). Sinar Grafika.

Putra, A. A. N. B. A., \& Kasih, D. P. D. (2013). Penjabaran Prinsip-Prinsip Business Judgment Rule Sebagai Doktrin. Kertha Negara: Journal Ilmu Hukum, 7(9), 1-17. https://ojs.unud.ac.id/index.php/Kerthanegara/article/view/54537/32321

Putranto, A. (2018). Kronologi Kasus Eks Dirut PertaminaKaren Agustiawan. CNN Indonesia. https://www.cnnindonesia.com/nasional/20180404185656-12288291/kronologi-kasus-eks-dirut-pertamina-karen-agustiawan

Rahadiyan, I. (2014). Kedudukan Bumn Persero Sebagai Separate Legal Entity Dalam Kaitannya Dengan Pemisahan Keuangan Negara Pada Permodalan BUMN. Jurnal Hukum Ius Quia Iustum, 20(4), 624-640. https://doi.org/10.20885/iustum.vol20.iss4.art7

Rimardhani, H., Hidayat, R., \& Dwiatmanto, D. (2016). Pengaruh Mekanisme Good Corporate Governance Terhadap Profitabilitas Perusahaan (Studi Pada Perusahaan Bumn Yang Terdaftar Di Bei Tahun 2012-2014). Jurnal Administrasi Bisnis S1 Universitas Brawijaya, 
http://administrasibisnis.studentjournal.ub.ac.id/index.php/jab/article/view/1226

Sjawie, H. F. (2017). Tanggung Jawab Direksi Perseroan Terbatas Atas Tindakan Ultra Vires. $\begin{array}{llll}\text { Jurnal Hukum } & \text { Prioris, } & 6(1), & 12-32 .\end{array}$ https://www.trijurnal.lemlit.trisakti.ac.id/index.php/prioris/article/view/1886

Subekti, T. (2008). Batasan Tanggung Jawab Direksi Atas Kerugian Perusahaan. Jurnal Dinamika Hukum, 8(1), 21-28. https://doi.org/10.20884/1.jdh.2008.8.1.21

Susanto. (2017). Harmonisasi Hukum Makna KeuanganNegara Dan Kekayaan Negara Yang Dipisahkan Pada Badan Usaha Milik Negara (Bumn) Persero. Prosiding Seminar Ilmiah Nasional: “Membangun Paradigma Kehidupan Melalui Multidisiplin Ilmu, 53(9), 1689_ 1699. https://doi.org/10.1017/CBO9781107415324.004

Utama, A. S. (2018). Independensi Pengawasan TerhadapBank BadanUsaha Milik Negara (Bumn) Dalam Sistem Hukum Nasional Di Indonesia. Soumatera Law Review, 1(1), 121. https://doi.org/10.22216/soumlaw.v1i1.3312

Wijaya, A. (2019). Implementation of the Doctrineof the BusinessJudgment Rule on Bankruptcy Law in Indonesia. Yuridika, 35(1), 1-14. https://doi.org/10.20473/ydk.v35i1.12436 